\title{
Bager
}

\section{Geologi og landformer i Norge}

\section{Af Peder Flansmose, DAGU}

\section{Går turen til Norge i nærmeste} fremtid, er det en god idé at have denne bog med i bagagen, hvis der står geologi på listen over oplevelser. Her får man en masse nyttig viden om Norges geologi og dannelse.

I denne bog på 130 sider bliver man sat godt og grundigt ind i Norges geologi.

Bogen er en fornyet og ombearbejdet udgave af "Skuret, værbitt", som blev udgivet første gang i 1992. Den er møntet på studerende og ikke mindst de mange naturinteresserede, som bevæger sig i den norske natur og undres over de forskellige landskabsformer.

\section{6 grundige afsnit}

Hvem har ikke kørt rundt $i$ landskabet og tænkt: Gad vide, hvordan dette landskab lige netop er kommet til at se sådan ud, er det is eller vand, der har skabt det, eller har andre ting måske haft en indflydelse. Det kan også være et fjeld - hvorfor ser det lige netop sådan ud, hvad enten det er takket eller pænt afrundet.

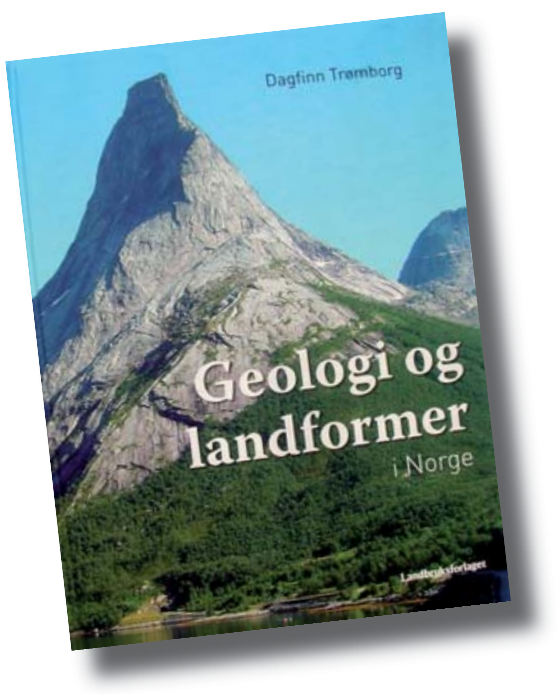

Utallige kan spørgsmålene være, og mange af dem vil man kunne finde svar på ved at bladre $\mathrm{i}$ bogen.

Bogen er inddelt i 6 afsnit, hvor det første beskriver, hvordan Norge blev dannet lige fra grundfjeldets dannelse for 4700 millioner år siden. Afsnittet omhandler også den vulkanske aktivitet og de forskellige istiders indvirkning på landets dannelse. Et kort, men let forståeligt indblik i, hvordan det hele startede.
De næste afsnit omhandler "Landsskabsformer i fast fjeld", "Landsskabsformer i løsmasser", "Landsskabsformer og typer", "Indsøer, myr og Bræer" og til sidst "Sten, jord, olie og gas".

I disse afsnit bliver man ført gennem samtlige landskabsformer og typer, som man kan støde på rundt omkring i Norge. Der bliver sat navn på de forskellige typer, og dannelsesprocessen bliver gennemgået på en let forståelig måde. Så at sige alle typer er illustreret med billeder, som mange gange siger mere, end en beskrivelse vil kunne gøre.

I det sidste afsnit beskrives de råstoffer, som Norge udnytter og udvinder til videreforarbejdning.

Det, at bogen er inddelt i de omtalte afsnit, gør, at den er utroligt nem at finde rundt $i$, og man kan rimeligt hurtig finde lige den landskabstype, man bevæger sig, i hvis det er det, der er brug for.

Alt $i$ alt en bog som alle, der rejser til Norge, eller interesserer sig for den geologiske udvikling, vil kunne få stort udbytte af.

Geologi og landformer i Norge af Dagfinn Trømborg. Landbruksforlaget, 140 sider indbundet, 398 Nkr. ISBN 82-529-2859-5.

\section{Lynhurtige rædselsfugle}

Rædselsfuglene - phorusrhaciderne en uddød race - var formentlig meget mere behændige og knap så svære som først antaget. Rekonstruktioner af de kødædende fugle tid viser et meget markant næb, runde øjenhuler og et hvælvet kranium - man har dog meget lidt information om kraniet for de helt store arter.

Et vigtigt nyt fund fra Miocæn (for ca. 15 mio. År siden) af et gigantisk fuglekranium fra Comallo, Argentina, afslører imidlertid nye vigtige forskelle mellem kranierne på store og små phorusrhacider. Forskerne fra Los Angeles naturhistoriske museum og dinosaurinstitut i USA, skriver, at rekonstruktioner af kranier af store phorusrhacider ud fra små kranier ikke er forsvarlige, og at korrelationen mellem deres kropssværhed og adræthed må revalueres. De store fugle kunne antageligvis løbe stærkt.

Det enorme kranium, man har fundet, måler fra næbspids til toppen af hovedet ca. $716 \mathrm{~mm}$ og er dermed det største kendte fuglekranium. Kropsvægten anslås til omkring $200 \mathrm{~kg}$.

Fuglene kunne ikke flyve, men bevæge sig med høj hastighed - op mod $70 \mathrm{~km} / \mathrm{t}$, når de jagede deres bytte, mener Luis $\mathrm{M}$. Chiappe fra Los Angeles naturhistoriske museum. Med det kæmpestore hovede var den også i stand til at fange krybdyr og mindre pattedyr. Lårbenets udformning afsluttet af tre tæer viser, at dyret kunne bevæge sig med høj hastighed

Pga. sin hurtighed og det kolossale næb antages det, at rovfuglen måske har været det dominerende rovdyr over en periode på flere millioner år på det sydamerikanske kontinent, indtil Sydamerika blev landfast med Nordamerika.

www.nature.com,JP/UVH 